The Journal of Animal \& Plant Sciences, 31(1): 2021, Page: 280-287

ISSN (print): 1018-7081; ISSN (online): 2309-8694

\title{
EFFECT OF DIFFERENT SUBSTRATES ON FISH PRODUCTION AND WATER QUALITY IN PERIPHYTON BASED POLYCULTURE OF MAJOR CARPS
}

\author{
J. Shafi ${ }^{*}$ K. N. Waheed, M. Zafarullah, Z. S. Mirza, T. Rasheed \\ Fisheries Research and Training Institute, Lahore, Pakistan \\ Corresponding author's email: javairiamalik@gmail.com
}

\begin{abstract}
The study was designed to assess the effects of periphyton grown on different substrates on water quality and production of major carps cultured in zero water exchange system. Three experimental treatments included; T1 (Control): without substrate, T2: using PVC pipes substrates, T3, using Bamboo poles substrates. Fish seed of Labeo rohita: Cirrhinus mrigala and Gibelion catla were stocked in cemented tanks in 1:1:1 ratio at stocking density of 3 fishm $^{-2}$ for 60 days period. Survival rate of L. rohita, C. mrigala and G. catla was significantly higher $(\mathrm{p}<0.05)$ in substrates based treatments. In T1, T2 \& T3, it was found to be $34.09 \%, 81.82 \%$ \& $90.91 \%$ for $L$. rohita $; 22.73 \%, 100.0 \%$ \& $100.0 \%$ for C. mrigala and $36.36 \%, 90.91 \%$ \& $100.0 \%$ for G. catla respectively. Total fish biomass of L. rohita, C. mrigala and G. catla harvested at the end of trial was 2.24, 4.32 and 1.42 times higher in treatment with bamboo poles as substrates and $1.18,3.64$ and 0.75 time higher in PVC pipes based treatment than that of control. Concentration of ammonia and nitrite was found to be significantly low in treatments with periphyton than control. High fish survival in periphyton based systems can be attributed to bioremediation through bioprocesses of their ubiquitous microbial biofilms.
\end{abstract}

Keywords: Periphyton biomass, Biofilms, water quality, major carps, fish production.

\section{INTRODUCTION}

Aquaculture, a rapidly developing food production system, ensures increasing demand of the protein supply for growing world population. However, sustainable development of the sector necessitates to cope with the challenges of negative environmental impacts due to production of nutrient rich water and high feed cost. Several novel techniques have been practiced on this basis that improve the nutrient conversion efficiency in the aquaculture water. One of these strategies is based on the development of microbial biofilms that are attached to a substratum within the culture unit and referred as periphyton (Azim and Little, 2006). Periphyton can be considered as a microecosystem composed of a complex matrix with embedded microorganisms attached to the substratum that has the natural ability to respond and recuperate from stress (Sabater et al., 2007). This composite of sessile aquatic biota comprises of protozoans, fungi, bacteria, planktons, benthic organisms and invertebrates along with calcium carbonate and detritus attached to a submerged substratum (Azim and Asaeda, 2005).

Due to their higher nutrient conversion efficiency, periphyton matrix not only reduces the negative effects of pond water effluents but also improves the water quality within the aquaculture system, thereby, leading to higher fish production (Wu, 2017). Materials that provide large surface area like tree branches, aquatic vascular plants, bamboos, and synthetic polymers (e.g.
PVC pipes) can be used for periphyton production (Ekram-Ul-Azim, 2001). Periphyton based systems, therefore, can serve as feasible option to be employed for sustainable aquaculture practices.

In Pakistan, various anthropological activities and overfishing have led to the loss of biodiversity in our natural water bodies and reduction in wild fish catches (Shafi et al., 2018). Sustainable development of aquaculture sector is, therefore, a crucial prerequisite to ensure the food security for the increasing population of the country and to fill the gap between the demand and supply of fish and fish products. Although aquaculture is progressing at fast rate in the country and enormous research is being carried out to get increased fish production through natural and supplementary feeding, none of the earlier investigations have evaluated the effect of using periphyton in fish culture systems. The present study was, therefore, carried out to evaluate the effect of periphyton based systems on fish culture and water quality to aid in the use of low cost technologies for development of aquaculture sector. The study assessed the effect of using natural and synthetic substrates for periphyton growth on water quality and fish survival \& production in polyculture system of major carps in zero water exchange (ZWE) system. Bamboo poles and PVC pipes were used in this study to compare the efficacy of natural and artificial substrates for periphyton growth. 


\section{MATERIALS AND METHODS}

Tanks preparation and fertilization: Fish culture experiment was conducted for 60 days (OctoberNovember, 2018) to evaluate the effect of periphyton on fish growth. The experiment was conducted in cemented tanks at Fisheries Research and Training Institute, Lahore, Pakistan. Average surface area of each tank was $20.7 \mathrm{~m}^{2}$ with average water depth of $0.90 \mathrm{~m}$. Bottom of tanks was covered with $0.30 \mathrm{~m}$ thick soil layer. There were three experimental treatments; T1: without substrate, T2: with PVC pipes as substrate and T3: with bamboo poles as substrate. Each experiment treatment was tested in duplicate. Submerged bamboo pole and PVC stick with uniform surface area $\left(0.06 \mathrm{~m}^{2}\right)$ were installed at a rate of 5 substrates $/ \mathrm{m}^{2}$ in $\mathrm{T} 2$ and $\mathrm{T} 3$. Additional surface area provided by substrates installation was $5.5 \mathrm{~m}^{2}$ in each treatment. In order to use optimum pond fertilization, fertilizer programme that provided $\mathrm{N}: \mathrm{P}_{2} \mathrm{O}_{5}$ of 1.1:1.0 was adopted following Azim et al. (2001a). Cow dung, urea and single super phosphate (SSP) were applied in tanks at the rate of 10 $\mathrm{kg}, 0.050 \mathrm{~kg}$ and $0.100 \mathrm{~kg}$ per tank, respectively and tanks were left for 15 days to allow sufficient production of periphyton on the provided substrates.

Fish Stocking and Tank Management: Fish seed of $L$. rohita: C. mrigala: G. catla (stocking ratio; 1:1:1) with initial weight of $0.81 \mathrm{~g} \pm 0.08 \mathrm{~g}, 3.16 \mathrm{~g} \pm 0.16 \mathrm{~g}$ and $3.9 \mathrm{~g}$ $\pm 0.55 \mathrm{~g}$ respectively were stocked in six experimental tanks at the stocking density of $3 \mathrm{fish} / \mathrm{m}^{2}$. Total initial fish biomass stocked in each tank was recorded. Fish was supplied with soybean meal based supplementary feed ( $31 \%$ crude protein) at the rate of $2 \%$ fish body weight in each tank daily. Consumption of supplementary feed by fish was ensured by regularly monitoring the deposition of any uneaten feed on bottom mud of tanks. Urea and SSP were applied at the rate of $0.025 \mathrm{~g}$ and $0.050 \mathrm{~g} / \mathrm{tank}$ respectively on weekly basis throughout the experimental period (Azim et al., 2001a). Due to low water level and bottom soil content in tanks, organic manure was used only at initiation of experiment. There was no exchange of water (ZWE system) during the entire experimental period and fresh water was added only to compensate for water lost by evaporation and maintain it at constant level in tanks.

Water Quality Monitoring: Water abiotic quality parameters were measured on weekly basis and included temperature, dissolved oxygen $\left(\mathrm{mgL}^{-1}\right), \mathrm{pH}$, electrical conductivity $\left(\mathrm{EC}, \mu \mathrm{Scm}^{-1}\right)$, total alkalinity $\left(\mathrm{mgL}^{-1}\right)$, total hardness $\left(\mathrm{mgL}^{-1}\right)$, chloride content $\left(\mathrm{mgL}^{-1}\right)$, total ammonia-N (TAN, $\left.\mathrm{mgL}^{-1}\right)$ ), nitrite-N $\left(\mathrm{mgL}^{-1}\right)$, nitrate-N $\left(\mathrm{mgL}^{-1}\right)$, soluble reactive phosphorous $\left(\mathrm{mgL}^{-1}\right)$. Unionized ammonia-N content $\left(\mathrm{mgL}^{-1}\right)$ was calculated according to Boyd and Tucker (2012) using water TAN, $\mathrm{pH}$ and temperature. Water samples were collected between 10:00-11:00 on each sampling day, $30 \mathrm{~cm}$ below the water level. Temperature was measured by direct insertion of a laboratory thermometer in the tank water. Dissolved oxygen, $\mathrm{pH}$ and $\mathrm{EC}$ were measured with the aid of electronic meters. Total alkalinity, total hardness, chloride content, nitrite- $\mathrm{N}$, nitrate- $\mathrm{N}$ and soluble reactive phosphorous were measured using standard methods of APHA, 2012. Total ammonia-N was measured using Nessler method (ASTM, 2008).

Monitoring of Periphyton and Primary Productivity: For determination of moisture and ash content, periphyton mass were taken by scraping the respective substrate with the help of scalpel from an area of 94.20 $\mathrm{cm}^{2}$. Moisture and ash content of periphyton was determined following Azim et al. (2001a). For qualitative and quantitative analysis of phytoplankton and periphyton, water and periphyton samples were collected on weekly basis from the second month of experiment. For determination of plankton density, method of Azim et al. (2001b) with slight modification was adopted. Water sample $(1 \mathrm{~L})$ of water was collected $30 \mathrm{~cm}$ below the water surface and filtered through a phytoplankton net with $37 \mu \mathrm{m}$ mesh size. Residual biomass (RBM) retained on the top of the net was transferred quantitatively to a glass cylinder and made up to $100 \mathrm{ml}$ with distilled water. The RBM samples were preserved with concentrated formalin and stored in sealed plastic vials till further analysis. Sedgewick-Rafter counting chamber (SRC) was used for quantification of phytoplankton and zooplankton. RBM sample was shaken gently and $1 \mathrm{ml}$ was poured on Sedgewick-Rafter cell (1000 grids). Number of plankton in three randomly selected grids was counted and used to determine planktonic density. For periphyton analysis, an area of $12.56 \mathrm{~cm}^{2}$ from one substrate in each tank (bamboo pole/ PVC pipe) was scrapped with the help of a scalpel and periphyton biomass was transferred to a plastic bottle with $50 \mathrm{ml}$ distilled water. Samples were preserved with concentrated formalin for future examination. The compact mass of periphyton was gently grinded in the glass tissue grinder, transferred to glass cylinder, made up to $500 \mathrm{ml}$ with distilled water and quantified using SRC (Azim et al., 2001b). Qualitative analysis of phytoplankton and periphyton was carried out according to Ward and Whipple (1959) and Prescott (1984).

Fish Harvest: Tanks water was drained and fish were harvested at the end of 60 days culture period. Total fish biomass (gross production; gtank ${ }^{-1}$ ) and survival rate in each tank was recorded and fish growth and production parameters were calculated.

Statistical Analysis: Collected data on fish production, survival and water quality parameters was statistically analyzed through one-way ANOVA followed by post hoc analysis (Least Significant Difference Test) at 
significance level of .05. Independent t- test was used to compare the proximate quality of periphyton mass in two treatments $(p<.05)$. All statistical analysis was performed using SPSS version 22 following Field (2013).

\section{RESULTS AND DISCUSSION}

Fish culture has been associated with the discharge of nutrient rich aquaculture water containing compounds of nitrogen and phosphorous as well as organic matter in the receiving water bodies causing degradation of their water quality (Crab et al., 2007; Mugg et al., 2007). Moreover, drained water may introduce pathogenic microorganisms leading to poor microbial quality of receiving water reservoir (Thompson et al., 2002). Management of ammonia and other nitrogenous substances in pond involves optimum operation of biological processes in culture water that can maintain content of toxic compounds within safe limits. Bioprocesses involved in development and growth of periphyton within the culture system amplify nutrient conversion efficiency in water leading to increased transformation of toxic ammonia and nitrite to innocuous compounds (Sabater et al., 2007).

Although periphyton based aquaculture systems have been focused in earlier studies, most of the work in this field was done at the start of $21^{\text {st }}$ Century in Bangladesh (Wahab et al., 1999; Azim et al., 2001a; Ekram-Ul-Azim, 2001; Azim, et al., 2002; Azim et al., 2004; Rai et al., 2008). In some recent investigation, researchers have investigated the potential of periphyton based fish culture in Nepal and Brazil (Tortolero et al., 2016; Jha et al., 2018). The present study was a first pilot investigation to assess the potential of using periphyton in fresh water aquaculture in Pakistan.

Fish Survival and Production: Fish survival rate and production in substrates based treatments was significantly higher than that of control (Table 1). Survival rate of fish showed marked differences among treatments with and without substrate. For substrate based treatments, survival rate of all three fish species ranged from $80 \%$ to $100 \%$ while it was found to vary from $22 \%$ to $38 \%$ in the case of control (Table 1). Total fish biomass (gross production; gtank ${ }^{-1}$ ) of L. rohita, $C$. mrigala and $G$. catla harvested at the end of trial was 2.24, 4.32 and 1.42 times higher in treatments with bamboo poles as substrates than that of control (without substrate). For PVC pipes based treatments, total fish biomass was $1.18,3.64$ and 0.75 times higher than control treatment for L. rohita, C. mrigala and G. catla respectively. The results are in agreement with those of Azim et al. (2004), Cavalcante et al. (2011) and Reboucas et al. (2012) who have also reported higher fish production in periphyton based culture systems due to improved water quality. A comparison of the two substrates for periphyton growth showed that use of bamboo poles resulted in higher survival rate and fish production of $L$. rohita in comparison to PVC pipes. However, survival rate and production of L. rohita was significantly higher in PVC pipes based treatment than that of control.

Average weight gain and specific growth rate (SGR) of all three fish species didn't differ significantly between the substrate based treatments and control $(p<.05)$. Results of comparable fish growth in control treatment are in contradiction with those of Azim et al. (2002), Azim et al. (2004) and Rai et al. (2008) who reported improved growth performance of carps in the presence of periphytic communities. According to these studies, periphyton served as natural feed for fish resulting in higher fish growth. However, findings of present study are in agreement with those of Tortolero et al. (2016) and Jha et al. (2018) who showed that weight gain of carps in control treatment (without substrate and periphyton) was comparable to that of substrate based treatments. Tortolero et al. (2016) has attributed higher fish growth in control treatment to the periphytic communities grown on walls of tanks. In present study, the walls of tanks were periodically scrapped to remove any periphyton growth. It was also observed during the experiment that fish in substrate based treatments was consuming periphyton. However, higher fish growth in control treatment can be attributed to lower fish survival that led to reduced fish stocking density in this treatment. Due to low fish density, higher amount of supplemented feed was available to the fish that led to higher growth.

A comparison of two types of substrates showed that average weight gain of all fish species were higher in bamboo poles based treatment $(16.82 \mathrm{~g} \pm 2.01 \mathrm{~g}, 14.37 \mathrm{~g}$ $\pm 1.12 \mathrm{~g}$ and $13.27 \mathrm{~g} \pm 1.56 \mathrm{~g}$ for L. rohita, C. mrigala and $G$. catla respectively) as compared to those achieved in PVC pipes based treatment $(12.86 \mathrm{~g} \pm 0.50 \mathrm{~g}, 12.42 \mathrm{~g}$ $\pm 0.30 \mathrm{~g}$ and $9.52 \mathrm{~g} \pm 1.73 \mathrm{~g}$ for L. rohita, C. mrigala and $G$. catla respectively). Similar results have been reported by Jha et al. (2018) who achieved higher fish growth with the use of $20 \%$ density of natural substrates as compared to three evaluated densities of artificial substrates.

Monitoring of Water Quality: Results of water quality analysis are presented in Table 2. Presence or absence of substrate didn't affect water dissolved oxygen, $\mathrm{pH}$, electrical conductivity, total alkalinity, total hardness, chloride content which were found to be within suitable range for fish culture. These results are in accordance with those of Azim et al. (2001a), Ahsan et al. (2014) and Tortolero et al. (2016) who also reported that substrates availability didn't affect general water quality parameters of aquaculture water.

Graphical presentation of average content of nitrogenous compounds and variation of nitrite-N, nitrate-N and phosphorous content in water has been 
shown in Figure 1 (a-d). Content of TAN, unionized ammonia-N and nitrite-N was significantly higher $(p<.05)$ in control treatment than in substrate based treatments. Average unionized ammonia-N in control treatment $\left(0.012 \mathrm{mgL}^{-1} \pm 0.0002 \mathrm{mgL}^{-1}\right)$ was found to be 3.8 times higher than its content in bamboo based treatment $\left(0.0036 \mathrm{mgL}^{-1} \pm 0.002 \mathrm{mgL}^{-1}\right)$ and 2.3 times higher than detected in PVC pipes based treatment $\left(0.0043 \mathrm{mgL}^{-1} \pm 0.0012 \mathrm{mgL}^{-1}\right)$. The results of higher unionized ammonia- $\mathrm{N}$ observed in control treatment are in agreement with earlier investigations carried out on periphyton based fish culture studied in tanks (Langis et al., 1988; Thompson et al., 2002) and in ponds (Azim et al., 2002; Azim et al., 2004) who have reported significantly higher ammonia concentration in control than that of periphyton based treatment due to higher rate of nitrification in the latter.

Level of toxic nitrogen compounds in water must be maintained within suitable limits for health and optimum growth of cultured fish that consequently leads to higher fish production. Problems of higher ammonia concentration in fish ponds are often dealt with occasional or regular water exchange that not only involves the pollution of receiving water reservoirs but is also uneconomical practice for large ponds (Tucker and Hargreaves, 2012). In general, maximum unionized ammonia-N concentration is recommended to be less than $0.02 \mathrm{mgL}^{-1}$ for freshwater aquatic life (United States Army Corps of Engineers, 1982). Lethal concentration (LC50, 24 hours) of unionized ammonia-N has been reported to be $0.055 \mathrm{mgL}^{-1}$ and $0.045 \mathrm{mgL}^{-1}$ for $C$. mrigala and $G$. catla respectively (Tilak et al., 2002; Iqbal et al., 2013). In present study, highest mean unionized ammonia-N level $\left(0.012 \mathrm{mgL}^{-1}\right.$, detected in control treatment) was less than maximum acceptable level of $0.02 \mathrm{mgL}^{-1}$. However, it has been reported that unionized ammonia- $\mathrm{N}$ concentration follow a diurnal cycle in ponds and may vary from trace level in the morning to more than $1.0 \mathrm{mgL}^{-1}$ ammonia- $\mathrm{N}$ in midafternoon (Boyd, 2012). In current investigation, water quality assessment was carried out in the morning, therefore, there is possibility that in control treatment, unionized ammonia-N may rise to critical levels in the late hours of the day leading to fish mortality. However, this aspect of water quality requires further investigation.

Nitrite- $\mathrm{N}$ ranged from $0.028 \mathrm{mgL}^{-1} \pm 0.00 \mathrm{mgL}^{-1}$ in PVC pipes based treatment to $0.056 \mathrm{mgL}^{-1} \pm 0.065$ $\mathrm{mgL}^{-1}$ in control. Maximum acceptable levels for nitrite$\mathrm{N}$ are species specific and depend on pond conditions, however, a value of less than $0.60 \mathrm{mgL}^{-1}$ for freshwater aquatic life is recommended (with water chloride content higher than $10 \mathrm{mgL}^{-1}$ ) (Nordin et al., 2009). Nitrite-N content was found to be significantly higher in control treatment in present study, however, its average content $\left(0.056 \mathrm{mgL}^{-1}\right)$ was less than maximum acceptable value $\left(0.60 \mathrm{mgL}^{-1}\right)$. An examination of variation in nitrite-N during experimental period reveals that it remained consistently higher in control ponds after 3 weeks of initiation of experiment till $8^{\text {th }}$ week (Figure 1-b). Content of nitrate- $\mathrm{N}$ remained below the maximum recommended limit of $32.8 \mathrm{mgL}^{-1}$. Moreover, there was no significant difference in nitrate- $\mathrm{N}$ content found in three treatments (Figure 1-c).

Water phosphorous content was found to be significantly lower in $\mathrm{T} 1$ (control) than $\mathrm{T} 2$ and $\mathrm{T} 3$ (Figure 1-d). Its averaged content ranged from 0.240 $\mathrm{mgL}^{-1} \pm 0.077 \mathrm{mgL}^{-1}$ in control treatment to $0.613 \mathrm{mgL}^{-1}$ $\pm 0.057 \mathrm{mgL}^{-1}$ in PVC based treatment. According to Milstein et al. (2003), major flow of phosphorous in ponds is linked with phytoplankton development and process of decomposition occurring at the pond bottom whereas nitrogen cycling is mainly connected to periphyton based heterytrophic and autotrophic processes. Differences in TAN, unionized-ammonia-N, nitrite-N and water phosphorous content were not significant among two substrate based treatments.

Periphyton Biomass: Periphyton biomass was found to be higher in the case of bamboo poles $\left(9.22 \mathrm{mgcm}^{-2} \pm\right.$ $\left.0.45 \mathrm{mgcm}^{-2}\right)$ than that of PVC pipes $\left(7.98 \mathrm{mgcm}^{-2} \pm 1.41\right.$ $\mathrm{mgcm}^{-2}$ ), however, the difference was not significant statistically (Table 3). Periphyton biomass depends on multiple factors including nature of substrate, fertilization rate, taxonomic composition of communities colonizing on substrate, fish stocking combination and stocking ratio. Azim et al. (2001a) have reported periphyton biomass of $2.4 \mathrm{mgcm}^{-2}$ with $100 \%$ Gibelion catla and $0.68 \mathrm{mgcm}^{-2}$ with $100 \%$ L. rohita. Tortolero et al. (2016) also reported higher periphyton on natural substrate $(3.55$ $\left.\mathrm{mgcm}^{-2} \pm 2.57 \mathrm{mgcm}^{-2}\right)$ than artificial one $\left(0.69 \mathrm{mgcm}^{-2} \pm\right.$ $0.27 \mathrm{mgcm}^{-2}$ ) at $10 \%$ substrate density.

Moisture and ash content of periphyton biomass in two treatments has been shown in Table 3. There was no significant difference in proximate quality of periphyton grown on two different substrates. Moisture and ash content of periphyton ranged from 79\% - 80\% and $40 \%-46 \%$ respectively in two treatments. Ash free dry weight (AFDW) is an indicator of total organic mass in periphyton comprising of autotrophic and heterotrophic communities, alochthonous material and dead periphyton communities. According to the classification of Lakatos (1989), less than 25\% AFDW is considered as indicator of organic periphyton. In present study, there was no difference in composition of periphyton grown on natural or synthetic substrate on the basis of AFDW and periphyton biomass in both treatments was identified as inorganic-organic periphyton (Lakatos, 1989).

Taxonomic composition of periphyton: Quantitative analysis of water biotic parameters has been presented in Table 4. Classes of phytoplankton and zooplankton found in three treatments and periphyton found in two 
substrates based treatments have been shown in Table 5 and Table 6 respectively. For phytoplankton and zooplankton, there was no significant difference in their densities within the treatments (Table 4). Number of phytoplankton genera identified in three treatments was 8, 7 and 6 for PVC pipes based treatment, control and bamboo poles based treatment respectively. For zooplankton, 5 genera were identified in control and PVC pipes based treatment and 4 in bamboo poles based treatment. For periphyton, members of Bacillophyceae were found to be significantly higher $(p<.05)$ in bamboo poles based treatment than PVC pipes based treatments. However, there was no significant difference between the two substrate based treatments for members of Cyanophyceae. Gonium sp.; member of Chlorophyceae was only found in bamboo poles based treatment. Nine genera of periphyton were identified on bamboo poles while five were detected on PVC pipes. The results are in agreement with those of Tortolero et al. (2016) who also reported higher periphyton genera on natural substrate.

Table 1. Production and Survival of major carps (Mean $\pm \mathrm{SE}$ )

\begin{tabular}{|c|c|c|c|c|}
\hline $\begin{array}{l}\text { Fish } \\
\text { species }\end{array}$ & Treatment & T1 (Control) & $\begin{array}{c}\text { T2 (With PVC } \\
\text { pipes) }\end{array}$ & $\begin{array}{c}\text { T3 (With } \\
\text { bamboo poles) }\end{array}$ \\
\hline \multirow{8}{*}{ L. rohita } & Initial biomass $(\mathrm{g})$ & $18.65 \pm 1.25^{\mathrm{a}}$ & $21.90 \pm 3.5^{\mathrm{a}}$ & $19.10 \pm 1.6^{\mathrm{a}}$ \\
\hline & Final biomass (production, gtank ${ }^{-1}$ ) & $112.90 \pm 18.20^{\mathrm{a}}$ & $246.50 \pm 10.90^{\mathrm{b}}$ & $365.60 \pm 26.20^{c}$ \\
\hline & Survival rate $(\%)$ & $34.09 \pm 2.27^{\mathrm{a}}$ & $81.82 \pm 0^{\mathrm{b}}$ & $90.91 \pm 0^{\mathrm{c}}$ \\
\hline & Average weight gain $(\mathrm{g})$ & $14.17 \pm 1.37^{\mathrm{a}}$ & $12.86 \pm 0.50^{\mathrm{a}}$ & $16.68 \pm 2.01^{\mathrm{a}}$ \\
\hline & Average initial weight $(\mathrm{g})$ & $0.79 \pm 0.07^{\mathrm{a}}$ & $0.81 \pm 0.11^{\mathrm{a}}$ & $0.82 \pm 0.065^{\mathrm{a}}$ \\
\hline & Average final weight $(\mathrm{g})$ & $14.96 \pm 1.44^{\mathrm{a}}$ & $13.67 \pm 0.60^{\mathrm{a}}$ & $17.51 \pm 2.08^{\mathrm{a}}$ \\
\hline & SGR & $4.90 \pm 0.013^{\mathrm{a}}$ & $4.72 \pm 0.15^{\mathrm{a}}$ & $5.08 \pm 0.07^{\mathrm{a}}$ \\
\hline & Initial biomass $(\mathrm{g})$ & $78.80 \pm 2.40^{\mathrm{a}}$ & $73.30 \pm 0.90^{\mathrm{a}}$ & $73.05 \pm 0.45^{\mathrm{a}}$ \\
\hline \multirow{6}{*}{$\begin{array}{c}\text { C. } \\
\text { mrigala }\end{array}$} & Final biomass (production, gtank ${ }^{-1}$ ) & $73.15 \pm 14.63^{\mathrm{a}}$ & $339.30 \pm 7.90^{b}$ & $389.2 \pm 25.20^{b}$ \\
\hline & Survival rate $(\%)$ & $22.73 \pm 4.54^{\mathrm{a}}$ & $100.0 \pm 0.0^{\mathrm{b}}$ & $100.0 \pm 0.0^{\mathrm{b}}$ \\
\hline & Average weight gain $(\mathrm{g})$ & $11.31 \pm 0.10^{\mathrm{a}}$ & $12.42 \pm 0.30^{\mathrm{a}}$ & $14.37 \pm 1.12^{\mathrm{a}}$ \\
\hline & Average initial weight $(\mathrm{g})$ & $3.32 \pm 0.065^{\mathrm{a}}$ & $3.00 \pm 0.060^{\mathrm{a}}$ & $3.32 \pm 0.020^{\mathrm{a}}$ \\
\hline & Average final weight (g) & $14.63 \pm 0.071^{\mathrm{a}}$ & $15.42 \pm 0.36^{\mathrm{a}}$ & $17.69 \pm 1.14^{\mathrm{a}}$ \\
\hline & SGR & $2.53 \pm 0.07^{\mathrm{a}}$ & $2.73 \pm 0.005^{\mathrm{a}}$ & $2.78 \pm 0.01^{\mathrm{a}}$ \\
\hline \multirow{7}{*}{ G. catla } & Initial biomass $(\mathrm{g})$ & $86.65 \pm 3.65^{\mathrm{a}}$ & $81.3 \pm 4.90^{\mathrm{a}}$ & $86.55 \pm 4.35^{\mathrm{a}}$ \\
\hline & Final biomass (production, gtank $^{-1}$ ) & $165.00 \pm 25.00^{\mathrm{a}}$ & $288.97 \pm 49.83^{\mathrm{b}}$ & $394.25 \pm 26.66^{\mathrm{b}}$ \\
\hline & Survival rate $(\%)$ & $36.36 \pm 4.54^{\mathrm{a}}$ & $90.91 \pm 0.0^{\mathrm{b}}$ & $100.0 \pm 0.0^{\mathrm{b}}$ \\
\hline & Average weight gain (g) & $14.74 \pm 0.18^{\mathrm{a}}$ & $9.52 \pm 1.73^{\mathrm{a}}$ & $13.27 \pm 1.56^{\mathrm{a}}$ \\
\hline & Average initial weight (g) & $4.74 \pm 0.52^{\mathrm{a}}$ & $3.62 \pm 0.53^{\mathrm{a}}$ & $3.88 \pm 0.40^{\mathrm{a}}$ \\
\hline & Average final weight (g) & $18.96 \pm 1.00^{\mathrm{a}}$ & $13.14 \pm 2.26^{\mathrm{a}}$ & $17.14 \pm 1.16^{\mathrm{a}}$ \\
\hline & SGR & $2.52 \pm 0.15^{\mathrm{a}}$ & $1.16 \pm 0.24^{\mathrm{a}}$ & $2.48 \pm 0.29^{\mathrm{a}}$ \\
\hline
\end{tabular}

Mean values with different superscript letters in the same column (for each fish species) are statistically significant $(p<.05)$

Table 2. Water abiotic parameters (Mean \pm SE)

\begin{tabular}{|c|c|c|c|c|}
\hline \multirow[t]{2}{*}{ Water abiotic parameters } & \multirow{2}{*}{$\begin{array}{c}\text { Optimum/ } \\
\text { recommended } \\
\text { value }\end{array}$} & \multicolumn{3}{|c|}{ Treatments } \\
\hline & & T1 (Control) & $\begin{array}{c}\text { T2 (With PVC } \\
\text { pipes) }\end{array}$ & $\begin{array}{c}\text { T3 (With } \\
\text { Bamboo poles) }\end{array}$ \\
\hline Temperature $\left({ }^{\circ} \mathrm{C}\right)$ & $20-32$ & $23.74 \pm 0.02^{\mathrm{a}}$ & $23.59 \pm 0.65^{\mathrm{a}}$ & $23.76 \pm 0.025^{\mathrm{a}}$ \\
\hline $\mathrm{DO}\left(\mathrm{mgL}^{-1}\right)$ & $>5$ & $5.71 \pm 0.004^{\mathrm{a}}$ & $5.27 \pm 0.11^{\mathrm{a}}$ & $5.08 \pm 0.04^{\mathrm{a}}$ \\
\hline $\mathrm{pH}$ & $6.5-9.0$ & $8.66 \pm 0.078^{\mathrm{a}}$ & $8.49 \pm 0.076^{\mathrm{a}}$ & $8.41 \pm 0.028^{\mathrm{a}}$ \\
\hline $\mathrm{EC}\left(\mu \mathrm{Scm}^{-1}\right)$ & 1176 & $588.72 \pm 3.722^{\mathrm{a}}$ & $604.67 \pm 12.44^{\mathrm{a}}$ & $605.72 \pm 0.28^{a}$ \\
\hline Total alkalinity $\left(\mathrm{mgL}^{-1}\right)$ & $>50$ & $338.59 \pm 5.12^{\mathrm{a}}$ & $355.66 \pm 10.90^{\mathrm{a}}$ & $365.96 \pm 3.51^{\mathrm{a}}$ \\
\hline Total hardness $\left(\mathrm{mgL}^{-1}\right)$ & $>50$ & $291.41 \pm 4.40^{\mathrm{a}}$ & $296.56 \pm 8.72^{\mathrm{a}}$ & $316.97 \pm 5.82^{\mathrm{a}}$ \\
\hline Chloride content $\left(\mathrm{mgL}^{-1}\right)$ & $>20$ & $25.75 \pm 0.57^{\mathrm{a}}$ & $22.73 \pm 0.15^{\mathrm{a}}$ & $25.17 \pm 0.05^{\mathrm{a}}$ \\
\hline TAN $\left(\mathrm{mgL}^{-1}\right)$ & --- & $0.081 \pm 0.007^{\mathrm{a}}$ & $0.036 \pm 0.007^{\mathrm{b}}$ & $0.038 \pm 0.008^{\mathrm{b}}$ \\
\hline Unionized $\mathrm{NH}_{3}-\mathrm{N}\left(\mathrm{mgL}^{-1}\right)$ & $<0.02$ & $0.012 \pm 0.0002^{\mathrm{a}}$ & $0.0036 \pm 0.002^{b}$ & $0.0043 \pm 0.0012^{b}$ \\
\hline Nitrite-N $\left(\mathrm{mgL}^{-1}\right)$ & $<0.60 *$ & $0.056 \pm 0.006^{\mathrm{a}}$ & $0.031 \pm 0.003^{\mathrm{b}}$ & $0.028 \pm 0.0004^{\mathrm{b}}$ \\
\hline Nitrate-N $\left(\mathrm{mgL}^{-1}\right)$ & $<32.8$ & $0.249 \pm 0.023^{\mathrm{a}}$ & $0.173 \pm 0.065^{\mathrm{a}}$ & $0.088 \pm 0.017^{\mathrm{a}}$ \\
\hline Phosphorous (mgL ${ }^{-1}$ ) & Variable & $0.240 \pm 0.077^{b}$ & $0.589 \pm 0.075^{\mathrm{a}}$ & $0.613 \pm 0.057^{\mathrm{a}}$ \\
\hline
\end{tabular}

Mean values with different superscript letters in the same row are statistically significant $(p<.05)$,

*: for chloride content $>10 \mathrm{mgL}^{-1}$ 
Table 3. Characteristics of Periphyton biomass in substrate based treatments

\begin{tabular}{lcc}
\hline Parameter & Treatment \\
\cline { 2 - 3 } & T2 (With PVC pipes) & T3 (With bamboo poles) \\
\hline Periphyton biomass $\left(\mathrm{mgcm}^{-2}\right)$ & $7.98 \pm 1.41$ & $9.22 \pm 0.45$ \\
Moisture content $(\%)$ & $80.86 \pm 1.13$ & $79.51 \pm 1.81$ \\
Ash content (\%) & $45.23 \pm 5.58$ & $40.96 \pm 4.76$ \\
Ash free dry matter (\%) & $54.77 \pm 5.58$ & $59.04 \pm 4.80$ \\
Periphyton class & Inorganic-Organic Periphyton & Inorganic-Organic Periphyton \\
\hline Mean values with different superscript letters in the same row are statistically significant $(p<.05)$
\end{tabular}

Table 4. Water biotic parameters in three treatments (unitscm ${ }^{-2}$ unless stated otherwise, Mean $\pm \mathrm{SE}$ )

\begin{tabular}{cccc}
\hline Water biotic parameters & T1 (Control) & T2 (With PVC pipes) & T3 (With Bamboo poles) \\
\hline $\begin{array}{c}\text { Phytoplankton } \\
\text { Zooplankton } \\
\text { Periphyton }\end{array}$ & $1.04 \times 10^{5} \pm 1.02410^{3 \mathrm{a}}$ & $2.6 \times 10^{3} \pm 2.0 \times 10^{3 \mathrm{a}}$ & $1.1 \times 10^{3} \pm 5.30 \times 10^{2 \mathrm{a}}$ \\
$16.3 \pm 8.0^{\mathrm{a}}$ & $9.5 \pm 5.2^{\mathrm{a}}$ & $5.7 \pm 2.0^{\mathrm{a}}$ \\
i. Cyanophyceae* & & & \\
ii. Bacillariophyceae & --- & $2.8 \times 10^{6} \pm 2.9 \times 10^{5 \mathrm{a}}$ & $11.1 \times 10^{6} \pm 7.10^{6 \mathrm{a}}$ \\
iii. Unicellular algae & --- & $3.4 \times 10^{5} \pm 4.4 \times 10^{3 \mathrm{a}}$ & $8.06 \times 10^{4} \pm 6.3 \times 10^{5 \mathrm{~b}}$ \\
iv. Chlorophyceae & --- & $2.6 \times 10^{5} \pm 1.3 \times 10^{5 \mathrm{a}}$ & $1.4 \times 10^{6} \pm 2.6 \times 10^{4 \mathrm{a}}$ \\
\hline
\end{tabular}

*: Fragments $\mathrm{cm}^{-2}$; ND: Not detected; Mean values with different superscript letters in the same row are statistically significant $(p<.05)$

Table 5. List of planktons identified in three treatments.

\begin{tabular}{|c|c|c|c|c|c|}
\hline \multicolumn{2}{|c|}{ T1 (Control) } & \multicolumn{2}{|c|}{ T2 (With PVC pipes) } & \multicolumn{2}{|c|}{ T3 (With Bamboo poles) } \\
\hline Phytoplankton & Zooplankton & Phytoplankton & Zooplankton & Phytoplankton & Zooplankton \\
\hline i. Chlorophyceae & i. Eurotatoria & i. Chlorophyceae & i. Eurotatoria & i. Chlorophycea & i. Eurotatoria \\
\hline a. Gonium sp. & a. Polyarthra sp. & a. Gonium sp. & a. Polyarthra sp. & a. Trochiscia sp. & a. Polyarthra sp. \\
\hline b. Pediastrum sp. & b. Filinia sp. & b. Pediastrum sp. & b. Filinia sp. & b. Gonium sp. & ii. Monogononta \\
\hline c. Scenedesmus sp. & ii. Monogononta & c. Haematococcus sp. & ii. Monogononta & c. Pediastrum sp. & a. Keratella sp. \\
\hline ii.Bacillariophyceae & a. Keratella sp. & ii. Bacillariophyceae & a. Keratella $s p$. & d. Treubaria sp & b. Brachionus sp. \\
\hline a. Amphipleura sp. & b. Brachionus sp. & a. Bacillaria $s p$. & b. Brachionus sp. & ii. Cyanophyceae & iii. Maxillopoda \\
\hline iii. Cyanophyceae & iii. Maxillopoda & iii. Cyanophyceae & iii. Maxillopoda & a. Aphanocapsa sp. & a. Diaptomus sp. \\
\hline a. Aphanocapsa sp. & a. Diaptomus sp. & a. Aphanocapsa sp. & a. Diaptomus sp. & iii. Euglenoidea & \\
\hline iv. Euglenoidea & & iv. Euglenoidea & & a. Euglena sp & \\
\hline a. Euglena sp. & & a.Euglena sp & & & \\
\hline v.Trebouxiophyceae & & v. Trebouxiophyceae & & & \\
\hline a. Actinastrum sp. & & a. Crucigenia sp & & & \\
\hline & & vi.Zygnematophyceae & & & \\
\hline & & a. Closterium sp. & & & \\
\hline
\end{tabular}

Table 6. List of periphyton identified in substrate based treatments

\begin{tabular}{cc}
\hline T2 (With PVC pipes) & T3 (With Bamboo poles) \\
\hline i. Cyanophyceae & i.Cyanophyceae \\
a. Gloeotrichia $s p$. & a. Gloeotrichia sp. \\
ii. Bacillariophyceae & b. Oscillatoria sp. \\
a. Neidium sp. & c. Hyella fontana \\
b. Diatomella sp. & ii. Bacillariophyceae \\
c. Bacillaria sp. & a. Navicula sp. \\
d. Gomphoneis sp. & b. Mastogloia sp \\
& c. Anomoeoneis sp. \\
& d. Bacillaria sp. \\
& e. Amphipleura sp. \\
& iii. Chlorophyceae \\
\end{tabular}



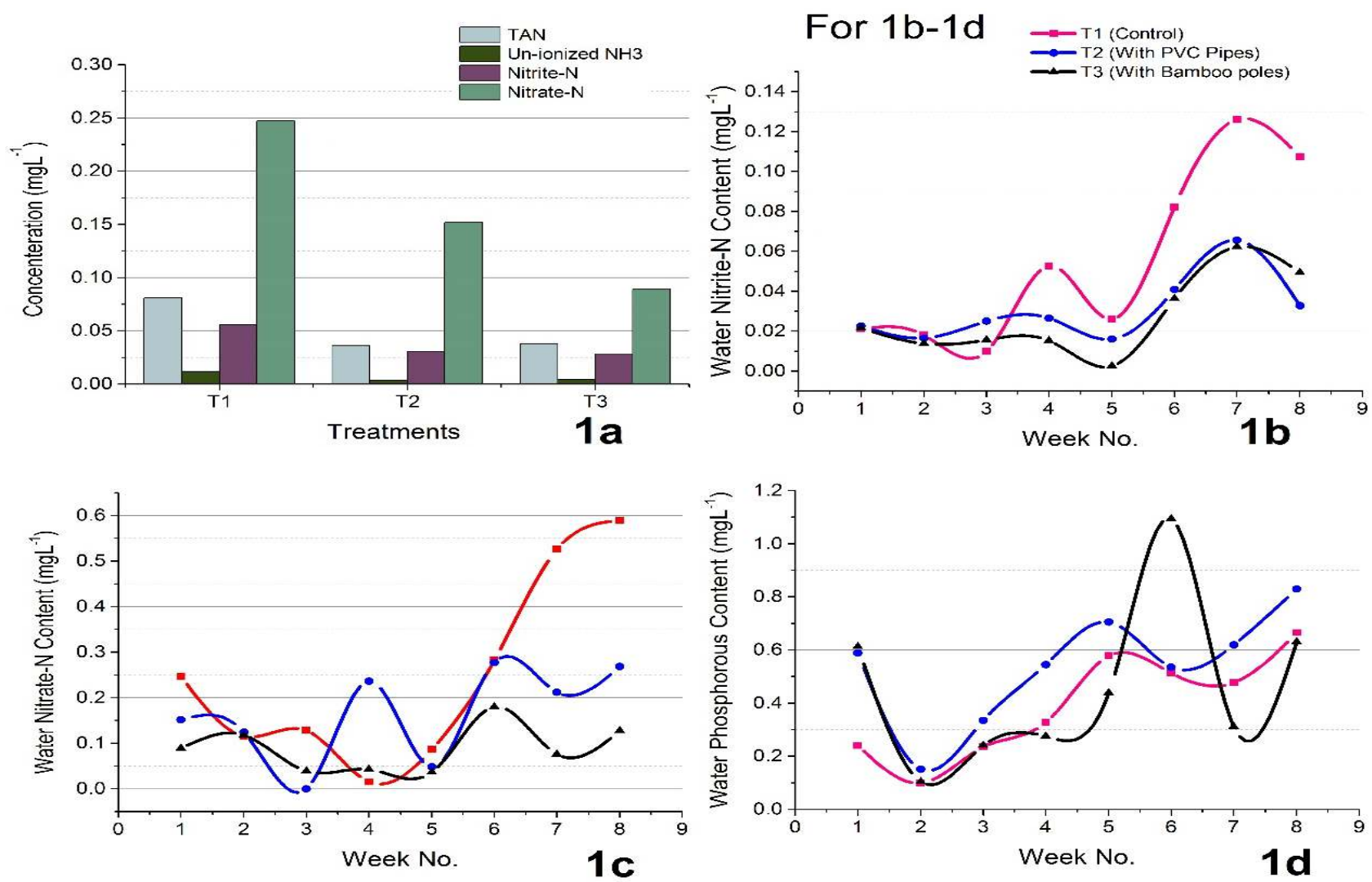

Figure 1. a: Average content of water nitrogenous compounds in three treatments, variation in b; water nitrite-N content, c; water nitrate- $N$ content, $d$; water phosphorous content during experimental period.

Conclusion: The present investigation has shown the potential of periphyton based culture in ZWE systems for polyculture of major carps through higher fish production and survival. In future, there is the need for extensive investigation of water quality in periphyton based ZWE systems for sound apprehension of the processes governing the development of ubiquitous microbial films and their role in nutrient conversion efficiency of the water column. Moreover, there is the need to investigate the potential of other low cost substrates and optimization of their density in culture system.

\section{REFERENCES}

Ahsan, M., M. Sharker, M. Alam, M. Siddik and A. Nahar (2014). Effects of addition of tilapia and periphyton substrates on water quality and abundance of plankton in freshwater prawn culture ponds. International J. Scientific Technological Research. 3(2): 1-6.

APHA (2012). Standard methods for the examination of water and wastewater. 22nd Ed. American Public Health Association; Washington, D.C. 1496 p.

ASTM (2015). D1426-15 Standard test methods for ammonia nitrogen in water. American Society for Testing and Materials, 1-7.
Azim, M., M. Wahab, A.A. van Dam, M. Beveridge, E. Huisman and M. Verdegem (2001a). Optimization of stocking ratios of two indian major carps, rohu (Labeo rohita ham.) and catla (Catla catla ham.) in a periphyton-based aquaculture system. Aquaculture. 203(1-2): 3349.

Azim, M., M. Wahab, A. van Dam, M. Beveridge and M. Verdegem (2001b). The potential of periphytonbased culture of two indian major carps, rohu Labeo rohita (hamilton) and gonia Labeo gonius (linnaeus). Aquacult. Res. 32(3): 209-216.

Azim, M., M. Verdegem, H. Khatoon, M. Wahab, A.A. van Dam and M. Beveridge (2002). A comparison of fertilization, feeding and three periphyton substrates for increasing fish production in freshwater pond aquaculture in Bangladesh. Aquaculture. 212(1-4), 227-243.

Azim, M., M. Wahab, P. Biswas, T. Asaeda, T. Fujino and M. Verdegem (2004). The effect of periphyton substrate density on production in freshwater polyculture ponds. Aquaculture. 232(1-4): 441453.

Azim, M. and T. Asaeda (2005). Periphyton structure, diversity and colonization. In Azim, M.E., M.C.M. Beveridge and A.A. van Dam (Eds.), 
Periphyton: Ecology, exploitation, and management (pp. 15-49). CABI Pub.; Wallingford, England. pp. 15-49.

Azim, M. and D. Little (2006). Intensifying aquaculture production through new approaches to manipulating natural food. $\mathrm{CAB}$ Reviews: Perspectives in Agriculture, Veterinary Science, Nutrition and Natural Resources. 1(62): 1-23.

Boyd, C.E. and C.S. Tucker (2012). Pond aquaculture water quality management. Springer Science+Business Media, LLC; New York, US. $700 \mathrm{p}$.

Cavalcante, D.D.H., S.R.D. Silva, P.D. Pinheiro and Á.D.C. Martins (2011). Lab-scale periphytonbased system for fish culture. Cienc Rural. 41(12): 2177-2182.

Crab, R., Y. Avnimelech, T. Defoirdt, P. Bossier and W. Verstraete (2007). Nitrogen removal techniques in aquaculture for a sustainable production. Aquaculture. 270(1): 1-14.

Ekram-Ul-Azim, M. (2001). The potential of periphytonbased aquaculture production systems. $\mathrm{PhD}$ Thesis, Wegeningen University, Wegeningen, The Netherlands.

Field, A.P. (2013). Discovering statistics using IBM SPSS statistics. 4th Ed. Sage; Los Angeles, California.

Iqbal, Z., N. Ijaz and J.A. Chaudhry (2013). Ammonia toxicity in Cirrhinus mrigala (hamilton) (cypriniformes, cyprinidae) fingerlings from fish hatchery Lahore, Pakistan. European J. Veterinary Medicine. 2(3): 143-153.

Jha, S., S. Rai, M. Shrestha, J.S. Diana, R.B. Mandal and H. Egna (2018). Production of periphyton to enhance yield in polyculture ponds with carps and small indigenous species. Aquaculture Reports. 9: 74-81.

Lakatos, G. (1989). Composition of reed periphyton (biotecton) in the hungarian part of lake Fertö. BFB-Bericht, 71: 125-134.

Langis, R., D. Proulx, J. de la Noüe and P. Couture (1988). Effects of a bacterial biofilm on intensive daphnia culture. Aquacult. Eng. 7(1): 21-38.

Milstein, A., M.E. Azim, M.A. Wahab and M.C.J. Verdegem (2003). The effects of periphyton, fish and fertilizer dose on biological processes affecting water quality in earthen fish ponds. Environ. Biol. Fishes. 68 (3): 247-260.

Mugg, J., A. Serrano, A. Liberti and M.A. Rice (2007). Aquaculture effluents: A guide for water quality regulators and aquaculturists. NRAC Publication, No. 00-003. University of Massachusetts Dartmouth, North Dartmouth, Massachusetts.

Nordin, R., L. Pommen and C. Meays (2009). Water quality guidelines for nitrogen (nitrate, nitrite, and ammonia). Water Stewardship Division, Ministry of Environment, Province of British Columbia.
Prescott, G.W. (1984). How to know the freshwater algae. Wm. C. Brown Co.; Dubuque, Iowa.

Rai, S., Y. Yi, M.A. Wahab, A.N. Bart and J.S. Diana (2008). Comparison of rice straw and bamboo stick substrates in periphyton-based carp polyculture systems. Aquacult. Res. 39(5): 464473.

Reboucas, V., N. Caldini, D. Cavalcante and F. Silva (2012). Interaction between feeding rate and area for periphyton in culture of nile tilapia juveniles. Acta Scientiarum. Animal Sciences. 34: 161-167.

Sabater, S., H. Guasch, M. Ricart, A. Romaní, G. Vidal, C. Klünder and M. Schmitt-Jansen (2007). Monitoring the effect of chemicals on biological communities. The biofilm as an interface. Analytical Bioanalytical Chemistry. 387(4): 1425-1434.

Shafi, J., Z.S. Mirza, N. Kosour and M. Zafarullah (2018). Assessment of water quality and heavy metals contamination of river Ravi in pakistan. Pakistan J. Analytical Environmental Chemistry. 19(2): 169-180.

Thompson, F.L., P.C. Abreu and W. Wasielesky (2002). Importance of biofilm for water quality and nourishment in intensive shrimp culture. Aquaculture. 203(3-4): 263-278.

Tilak, K., S. Lakshmi and T. Susan (2002). The toxicity of ammonia, nitrite and nitrate to the fish, Catla catla (hamilton). J. Environ. Biol. 23(2): 147-149.

Tortolero, S.A.R., B.A.S. Cavero, J.G. de Brito, C.C. Soares, J.L. da Silva Junior, J.C. de Almeida, G. Barlaya and K. Perar (2016). Periphyton-based jaraqui (Semaprochilodus insignis) culture with two types of substrates at different densities. Turk J Fish Aquat Sc. 16(2): 347-359.

Tucker, C. and J. Hargreaves. (2012). Ponds. In Tidwell, J. (Ed.), Aquaculture production systems. WileyBlackwell; Ames, Iowa. pp. 192-244.

United States Army Corps of Engineers (1982). West Tennessee tributaries project: Environmental impact statement. Howard Needles Tammen \& Bergendoff; Baton Rouge.

Wahab, M., M. Mannan, M. Huda, M. Azim, A. Tollervey and M. Beveridge (1999). Effects of periphyton grown on bamboo substrates on growth and production of indian major carp, rohu (Labeo rohita ham.). Bangladesh J. Fish. Res. 3(1): 1-10.

Ward, H.B. and G.C. Whipple (1959). Fresh-water biology. John Wiley \& Sons, Inc.; New York, USA.

Wu, Y. (2017). Periphyton: Functions and application in environmental remediation. Elsevier; Amsterdam, The Netherlands. 